\title{
PERBEDAAN ANTARA PERPUSTAKAAN KONVENSIONAL, DIGITAL, HIBRIDA DAN BOOKLESS
}

\author{
Nailul Husna*
}

Abstract: Conventional libraries are libraries that store and manage information inside a building. So the concept of conventional library is synonymous with the use of a place or building large enough.Along with the development of technology and see so many printed collections stored in the library then the concept of digital libraries present as one of the concepts used to minimize the weaknesses in the conventional library. For the application of digital libraries there are several things to note that is the provision of software, hardware and brainware. In addition to the concept of this digital library, the hybrid library also comes as a conceptual thought in the development of the library. The concept of hybrid library is a library concept that combines electronic collections with printed collections.Currently, in certain libraries have also implemented bookless library. The concept of this library is the concept of a library without any printed collections. The reading tool used in this bookless library uses ereader.

Keywords: Library, Conventional, Digital, Hybrid

\section{Pendahuluan}

Perkembangan teknologi dari hari ke hari mengalami perkembangan yang sangat pesat. Terkadang dengan pesatnya perkembangan tersebut kita kewalahan untuk menghadapinya. Perkembangan teknologi ini mempengaruhi berbagai macam aspek baik itu aspek ekonomi, politik, psikologi dan lain sebagainya. Termasuklah dalam hal ini perpustakaan juga menjadi dampak dari adanya perkembangan teknologi. Perpustakaan di tuntut untu

\footnotetext{
* Mahasiswa Pascasarjana Universitas Islam Negeri Sunan Kalijiga Yogyakarta. Email: nailulhusna25@gmail.com
} 
mengikuti perkembangan teknologi tersebut agar tidak ketinggalan zaman.

Pada awalnya perpustakaan yang ada masih menggunakan konsep perpustakaan konvensional yaitu perpustakaan yang menyimpan berbagai macam buku tercetak, yang kemudian disusun di rak-rak yang telah disediakan. Perpustakaan konvensional selalu dekat dengan konsep perpustakaan yang membutuhkan gedung atau tempat yang sangat besar mengingat bahwa koleksi-koleksi tercetak akan selalu bertambah. Selain itu, pada konsep perpustakaan konvensional ini penginputan data atau kegiatan perpustakaan lainnya masih bersifat manual.Sebagian perpustakaan atau pustakawan melihat hal ini merupakan suatu problem yang harus terselesaikan karena ketika semua kegiatan dilakukan secara manual maka akan memperlambat pekerjaan serta sistem temu kembali informasinya.

Kecanggihan teknologi yang terjadi sangat pesat telah membantu konsep perpustakaan menjadi perpustakaan yang lebih efisien baik bagi pustakawan dalam menyelesaikan tugasnya dan proses sistem temu kembali informasinya. Para pakar teknologi telah melahirkan software-software yang dapat diaplikasikan di perpustakaan yang dapat mempermudah semua kegiatan yang ada. Perpustakaan digital adalah salah satu konsep yang ditawarkan pada kecanggihan teknologi yang terjadi saat ini. Perpustakaan tidak lagi membutuhkan gedung-gedung yang besar untuk menyimpan koleksi dan informasi lainnya. Secara konseptual perpustakaan digital mencerminkan koleksi dan layanan perpustakaan dalam dunia fisik. Perpustakaan digital disini merupakan analog dari perpustakaan tradisional dalam hal keberagaman dan kompleksitas koleksinya, isinya mesti berupa media elektronik, disimpan dalam bentuk yang biasa dilihat.

Perkembangan teknologi semakin menunjukkan eksistensinya, begitu pula dengan perpustakaan. Perpustakaan selalu mengikuti perkembangan teknologi, karena di rasa pengelolaan perpustakaan dengan melibatkan perangkat teknologi akan memberi dampak positif bagi perkembangan perpustakaan. Selain perpustakaan digital, juga muncul konsep perpustakaan hibrida. Perpustakaan ini merupakan kelangsungan dari keberlanjutan perpustakaan digital, akan tetapi pada konsep perpustakaan ini menyediakan informasi 
baik koleksi tercetak maupun elektronik. Perpustakaan bookless akhir-akhir ini juga menjadi pilihan dalam konsep pembangunan perpustakaan. Konsep perpustakaan ini tidak menyediakan koleksti tercetak dan untuk membaca koleksinya dibutuhkan alat pembaca yang disebut e-reader.

Jika kita melihat perkembangan konsep-konsep perpustakaan yang telah ada, perkembangan teknologi merupakan salah satu faktor yang mampu mengubah paradigma konsep perpustakaan. Dengan adanya perubahan-perubahan yang terjadi ini maka dapat membantu perpustakaan dalam mengembangkan eksistensinya sebagai institusi yang tidak berjalan di tempat. Perubahan-perubahan yang terjadi di perpustakaan juga berdampak positif bagi pemustaka. Pemustaka akan tidak merasa bosan untuk berkunjung ke perpustakaan.

\section{Pembahasan}

\section{Perpustakaan Konvensional}

Ketika membicarakan tentang perpustakaan konvensinal maka tidak akan jauh dari membicarakan masalah tempat dan bangunan perpustakaan. Hal ini disebabkan oleh perpustakaan konvensional yang identik dengan susunan buku-buku yang membutuhkan tempat yang luas untuk menyusun dan menyimpan koleksi-koleksi buku tercetak. Perpustakaan adalah ruangan atau bagian sebuah gedung atau gedung itu sendiri yang digunakan untuk menyimpan buku dan terbitan lain yang biasanya disimpan menurut tata susunan tertentu untuk digunakan pembaca bukan untuk dijual. ${ }^{1}$ Dari pengertian perpustakaan diatas kita bisa menarik kesimpulan bahwa aspek tempat merupakan hal yang paling utama dan penting karena sebuah perpustakaan didefinisikan sebagai ruangan atau gedung dimana koleksinya terdiri dari berbagai macam bahan tercetak.

WTEC hyper library menjelaskan bahwa kerakteristik perpustakaan konvensional adalah: ${ }^{2}$

\footnotetext{
${ }^{1}$ Sulistyo Basuki. Pengantar IImu Perpustakaa dan Informasi. (Jakarta:Gramedia Pustaka Utama,1993),

${ }^{2}$ repository.usu.ac.id/bitstream/123456789/53087/4/Chapter\%20II.pdf diakses pada tanggal 20 Juni 2017
} 
- Emphashis on stronge and preservation of physical items, particularly books and periodicals.

- Cataloging at a high level rather than one of detail, e.g., author and subject indexes as opposed to full text.

- Browsing based on physical proximity of related materials, e.g., books on sociology are near one another on the shelves.

- Passitivity; informastion is physically assembled in one place; user must travel to the library to learn what is there and make use of it.

Berdasarkan teori di atas dapat diambil kesimpulan bahwa perpustakaan konvensional merupakan perpustakaan yang memiliki koleksi buku, manuskrip, jurnal, sumber informasi terekam lainnya dan terbitan yang terbatas pada bentuk cetak dengan akses manual. Perpustakaan konvensional memiliki keterbatasan yang berkaitan dengan penyimpnanan akses informasi, karena sebagian besar informasi dikumpulkan di perpustakaan.

\section{Perpustakaan Digital}

\section{Pengertian Perpustakaan Digital}

Perpustakaan digital berkembang sesuai dengan perkembangan teknologi yang terjadi saat ini. Perpustakaan digital telah mampu mengubah paradigma perpustakaan konvensional berubah menjadi perpustakaan yang lebih maju. Perpustakaan digital merupakan sebuah sistem yang memiliki berbagai layanan dan obyek informasi yang mendukung akses obyek informasi tersebut melalui perangkat digital. The digital library initiatives menggambarkan perpustakaan digital sebagai lingkungan yang bersama-sama memberi koleksi, pelayanan dan manusia untuk menunjang kreasi, diseminasi, penggunaan dan pelestarian data, informasi dan pengetahuan. ${ }^{3}$ Perpustakaan digital bisa dikatakan sebagai format baru dalam dunia perpustakaan yang mampu memberi kemudahan dalam mengelola data, menyimpan serta memberikan informasi kepada pemustaka lebih cepat. Federasi perpustakaan di Amerika

\footnotetext{
${ }^{3}$ Imam Yuadi. Perpustakaan Digital: Paradigma, Konsep dan Teknologi Informasi yang Digunakan.1 http://journal.unair.ac.id/filerPDF/PERPUSTAKAAN\%20DIGITAL.pdf diakses pada tanggal 26 Juni 2017.
} 
Serikat juga memberikan batasan istilah tentang perpustakaan digital yaitu sebagai berikutt: ${ }^{4}$

"Digital Libraries are organizations that provide the resources, including the specialized staff, to select, structure, offer intellectual acces to, interpert, distribute, preserve the integrity of, and ensure the persistence over time of collections of digital works so that they are readily and economically avaible for use by a defined community or set of communitites."

Pengertian tentang arsip digital diatas terlihat bahwa organisasi membutuhkan pegawai dengan tata kerja dan tujuan kerja, serta komunitas yang diharapkan dapat memanfaatkan jasa mereka. Konsep perpustakaan digital ini seringkali dihubungkan dengan organisasi yang mengoleksi rujukan berbasis web di internet. Yang terakhir pemaknaan perpustakaan digital lebih luas yaitu menyediakan sumber-sumber digital disamping pegawai dengan tata kerja dan tujuan kerja serta masyarakat yang diharapkan dapat memanfaatkan layanan perpustakaan. Perpustakaan digital mempunyai tiga karakteristik utama menurut National Science Foundation yaitu: ${ }^{5}$

1. Memakai teknologi yang mengintegrasikan kemampuan menciptakan, mencari dan menggunakan informasi dalam berbagai bentuk di dalam sebuah jaringan digital yang tersebar luas.

2. Memiliki koleksi yang mencakup data dan meta data yang saling mengaitkan berbagai data, baik di lingkungan internal maupun eksternal.

3. Merupakan kegiatan mengoleksi dan mengatur sumber daya digital yang dikembangkan bersama-sama komunitas pemakai jasa untuk memenuhi kebutuhan informasi komunitas tersebut.

Perpustakaan digital awalnya muncul dengan adanya otomasi perpustakaan dimana fungsi-fungsi perpustakaan dikerjakan dengan bantuan komputer. Otomasi perpustakaan ini berkembang sekitar pada tahun 1980 an dan pada saat itu hanya perpustakaan-

\footnotetext{
${ }^{4}$ Putu Laxman Pendit. Perpustakaan Digital dari A sampai Z. (Jakarta: Cita Karyakarsa Mandiri, 2008), 29

${ }^{5}$ Ibid., 9
} 
perpustakaan besar yang menerapkan sistem ini. Kemudian pada awal 1990 an muncullah perangkat lunak yang mampu mengotomasi hampir dari seluruh perpustakaan seperti OPAC (Online Public Access Catalogue), kontrol sirkulasi, pengadaan bahan perpustakaan, manajemen koleksi, manajemen keanggotaan dan lain sebagainya. Pada masa ini komunikasi antar perpustakaan dapat dilakukan dengan mudah dan lancar. Kemudian pada tahun 1994, Library of Congres mengeluarkan rancangan National Digital Library dengan menggunakan tampilan dokumen elektronik, penyimpanan dan penelusuran teks secara elektronikm dan teknologi lainnya terhadap koleksi cetak dan non cetak. ${ }^{6}$ Menurut Griffin, telah terjadi peledakan pertumbuhan ketertarikan dalam perkembangan dan pemakaian perpustakaan digital. ${ }^{7}$ Adapun faktor-faktor yang menunjang pengembangan perpustakaan digital antara lain:

a) Telah tersedianya teknologi komputer dan komunikasi yang memungkinkan dilakukannya penciptaan, pengumpulan dan manipulasi informasi.

b) Tersedianya infrastruktur jaringan internasional untuk mendukung sambungan dan kemampuan pengoperasian bagi pengguna.

c) Semakin berkembangnya informasi yang berbasis online

d) Kerangka akses internet telah muncul dimana-mana.

Ada beberapa hal yang mendasari pemikiran tentang perlunya dilakukan digitasi perpustakaan adalah sebagai berikut:

a) Perkembangan teknologi informasi di komputer semakin membuka peluang-peluang baru bagi pengembangan teknologi informasi perpustakaan yang murah dan mudah diimplementasikan oleh perpustakaan di Indonesia. Oleh karena itu, saat ini teknologi informasi sudah menjadi keharusan bagi perpustakaan di Indonesia, terlebih untuk menghadapi tuntutan kebutuhan bangsa Indonesia sebagai masyarakat yang berbasis pengetahuan terhadap informasi yang akan datang.

\footnotetext{
${ }^{6}$ Yuyun Widayanti. Pengelolaan Perpustakaan Digital. (STAIN Kudus: Jawa Tengah, 2015)

${ }^{7}$ lbid., 127
} 
b) Perpustakaan sebagai lembaga edukatif, informatif, preservatif dan rekreatif yang diterjemahkan sebagai bagian aktivitas ilmiah, tempat penelitian, tempat pencarian data/ informasi yang otentik, tempat penyimpanan, tempat penyelenggaraan seminar dan diskusi ilmiah, tempat rekreasi edukatif dan kontemplatif bagi masyarakat luas. Maka perlu didukung dengan sistem teknologi informasi masa kini dan masa yang akan datang yang sesuai dengan kebutuhan untuk mengkomodir aktivitas tersebut, sehingga informasi dari seluruh koleksi yang ada dapat diakses oleh berbagai pihak yang membutuhkannya dari dalam maupun luar negeri.

c) Dengan fasilitas digitasi perpustakaan, maka koleksi-koleksi yang ada dapat dibaca/ dimanfaatkan oleh masyarakat luas baik di Indonesia, maupun dunia internasional.

d) Volume pekerjaan perpustakaan yang akan mengelola puluhan ribu hingga ratusan ribu, bahkan bisa jutaan koleksi, dengan layanan mencakup masyarakat akademik (peserta didik, tenaga kependidikan dan masyarakat luas), sehingga perlu didukung dengan sistem otomasi yang futuristik (punya jangkauan kedepan), sehingga selalu dapat memberikan layanan yang prima.

e) Saat ini sudah banyak perpustakaan, khususnya di Perguruan Tinggi dengan kemampuan dan inisiatifnya sendiri telah merintis pengembangan teknologi informasi dengan mendigitasi perpustakaan (digital library) dan library automation yang saat ini sudah mampu membuat Jaringan Perpustakaan Digitasi Nasional ( Indonesian Digital Library Network).

\section{Kekuatan dan Kelemahan Perpustakaan Digital}

Penerapan perpustakaan digital sudah banyak dilakukan di berbagai macam perpustakaan apalagi perpustakaan yang ada di luar negeri. Perpustakaan digital ini banyak memiliki kekuatan atau keuntungan bila dibandingkan dengan perpustakaan konvensional 
(manual). Beberapa keunggulan perpustakaan digital diantaranya yaitu sebagai berikut: ${ }^{8}$

1) Long distance service, artinya dengan perpustakaan digital, pengguna bisa menikmati layanan sepuasnya, kapanpun dan dimanapun.

2) Akses yang mudah, akses perpustakaan digital lebih mudah bila dibandingkan dengan perpustakaan konvensional, karena pengguna tidak perlu dipusingkan dengan mencari di katalog dengan waktu yang lama.

3) Murah (cost efective), perpustakaan digital tidak memerlukan banyak biaya. Mendigitalkan koleksi perpustakaan lebih murah bila dibandingkan dengan membeli buku dalam bentuk tercetak.

4) Mencagah duplikasi dan plagiat, dengan adanya perpustakaan digital, maka proses plagiat bisa dikurangi, karena format yang dalam penyimpanannya dalam bentuk PDF, maka koleksinya hanya bisa dibaca oleh pengguna, tanpa bisa mengeditnya.

5) Publikasi karya secara global, dengan adanya perpustakaan digital karya-karya dapat dipublikasikan secara global ke seluruh dunia dengan bantuan internet.

Perpustakaan digital selain mempunyai beberapa keuntungan juga mempunyai beberapa kelemahan. Adapun kelemahan dari perpustakaan digital adalah sebagai berikut:

1) Pengarang tidak semuanya yang mengizinkan karyanya untuk didigitalkan, sehingga hal ini menjadi suatu kendala dalam pendigitalan koleksi. Pengarang akan berpikir tentang royalti yang akan diterima bila karyanya didigitalkan.

2) Masih banyaknya masyarakat khususnya Indonesia yang tidak paham akan teknologi. Apalagi jika perpustakaan digital ini diterapkan di perpustakaan yang berada di pedesaan.

3) Masih banyak pustakawan yang tidak paham tentang cara bagaimana mendigitalkan koleksi perpustakaan. Ini merupakan satu kendala yang harus dihadapi. Untuk

\footnotetext{
${ }^{8}$ Gatot Subrata. Perpustakaan Digital. (Perpustakaan UM, 2009), 7
} 
pustakawan biasanya akan diadakan pelatihan-pelatihan dalam mendigitalisasikan koleksi perpustakaan karena dalam proses pendigitalan membutuhkan keterampilan khusus.

\section{Infrastruktur Perpustakaan Digital}

Untuk menerapkan perpustakaan digital harus ada infrastruktur-infrastruktur yang harus dipenuhi. Perangkat utama yang diperlukan dalam perpustakaan digital adalah computer personal ( $\mathrm{PC}$ ), internet (inter-networking), dan world wide web (WWW). ${ }^{9}$ Sistem informasi juga diperlukan dalam menerapkan perpustakaan digital. Menurut Sucahyo ada tiga elemen penting yang diperlukan dalam pengembangan sistem informasi yaitu perangkat keras (hardware), perangkatlunak (software) dan manusia (brainware). ${ }^{10}$ Perangkatkeras yang dimaksudadalahsebagaiberikut:

1) Web server, yaitu server yang akanmelayanipermintaanpermintaanlayananweb page daripengguna internet.

2) Database server, yaitujantungsebuahperpustakaan digital karena di sinilahkeseluruhankoleksidisimpan.

3) FTP server, yaituuntukmelakukankirim/ terimaberkasmelaluijaringan computer.

4) Mail server, yaitu server yang melayanisegalasesuatu yang berhubungandengansuratelektronik (e-mail)

5) Printer server, yaituuntukmenerimapermintaanpermintaanpercetakan, mengaturantriannyadanmemprosesnya.

6) Proxy server, yaituuntukpengaturankeamananpenggunaan internet daripemakai-pemakai yang tidakberhakdanjugadapatdigunakanuntukmembatasikesitu s-situs yang tidakdiperkenalkan.

\section{Isu-Isu dalam Perpustakaan Digital}

Perpustakaan digital dianggap memang sebagai salah satu alternatif yang diambil dalam menangani banyaknya koleksi-koleksi

\footnotetext{
${ }^{9}$ Ibid, 8

${ }^{10}$ SucahyodanYudhoGiri.InfrastrukturPerpustakaan Digital (Jakarta: Sagung Seto,2006), 26
} 
tercetak yang disimpan di perpustakaan. Ada beberapa isu-isu yang berhubungan dengan perpustakaan digital yaitu:

1. Hak Cipta (copy right).

Arti dari hak cipta ini adalah untuk melindungi karya seseorang dari penggandaan sewenang-wenang sehingga seseorang penulis mendapatkan keuntungan dari ciptaannya untuk meneruskan kreatifitasnya. ${ }^{11}$ Persoalan hak cipta ini menjadi salah satu dampak dari perkembangan teknologi yang diterapkan di perpustakaan.

Pada perpustakaan digital local content merupakan objek yang harus dilindungi hak ciptanya. Untuk menangani masalah ini hak cipta karya yang asli akan diberikan user id untuk mengakses dan akan hanya menampilkan abstraknya saja.

\section{Preservasi Sumber Digital}

Preservasi merupakan unsur pengelolaan, keuangan, cara penyimpnanan, sumber daya manusia, maupun tehnik yang digunakan untuk pelerstarian bahan pustaka, maupun informasi yang dikandungnya. ${ }^{12}$ Ada beberapa tujuan preservasi yang dapat dirumuskan sebagai berikut: ${ }^{13}$

a. Resiko yang disebabkan oleh spesifikasi format obyek digital itu sendiri, misalnya format digital hanya dapat di baca oleh prosram tertentu.

b. Resiko yang disebabkan oleh karakter perangkat lunak untuk membaca obyek digital, termasuk system operasi, program aplikasi dan lain-lain.

c. Resiko yang di timpulkan oleh perangkat keras, termasuk jenis medianya (CD,DVD, Disk dan CPU).

d. Resiko yang di timbulkan dengan kaitan-kaitan yang di atas dengan kelembagaan tertentu, misalnya pemilik obyek digital, vendor dan lain-lain.

e. Resiko yang muncul dari pangkalan data itu sendiri, dari segi arsitektur, pengorganisasian dan lain-lain.

\footnotetext{
${ }^{11}$ Sulistyo Basuki. Pengantar Ilmu Perpustakaan dan Informasi (Jakarta: Gramedia Pustaka Utama, 1993),95

${ }^{12}$ Lasa HS. Leksikon Kepustakawanan Indonesia (Yogyakarta: Pustakawan UGM, 2000), 151

${ }^{13}$ J.M. Dereau dan D.W.G. Cleneans. Dasar-Dasar Pelestarian dan Pengawetan Bahan Pustaka: Principle For The Preservation and Konservation of Library Materials. (Jakarta: Perpustakaan Nasional RI, 1990),2.
} 
f. Resiko yang muncul dalam proses migrasi atau transformasi objek digital, baik yang bersifat mekanis maupun administrative.

3. Plagiarisme

Kemudahan dalam mengakses internet juga memberikan kemudahan plagiarisme karya-karya local content. Ada beberapa argumentasi tentang pembukaan akses koleksi local content: ${ }^{14}$

a. Plagiarisme tidak akan pernah dapat dihapuskan tetapi dapat diminimlisasi.

b. Setiap penulis ternyata akan sangat senang bila karyanya dibaca dan dikutip oleh akademisi/ peneliti. Hal itu sangat berguna untuk pengembangan ilmu pengetahuan.

c. Peran perpustakaan dan pustakawan adalah untuk mendiseminasi informasi seluas mungkin untuk pengembangan ilmu pengetahuan.

d. Penggunaan perpustakaan yang memang memiliki niat untuk menjiplak akan selalu menemukan cara untuk mengakali batasan-batasan yang ada.

\section{Perpustakaan Hibrida dan Bookless}

Hibryd library merupakan campuran bahan-bahan cetakan seperti buku, majalah dan juga bahan koleksi yang berupa elektronik. Seperti yang dikemukakan oleh Hutton hybrid library adalah:

"A hybrid library is a library where "new" electronic information resources and 'traditional' hardcopy resources co exist and are brought together in an integrated information services, accessed via electronic gateways available both on site, like a traditional library, and remotely via internet or local computer network". ${ }^{15}$

Hybrid library adalah merupakan bentuk perpaduan antara perpustakaan konvensional dan perpustakaan digital atau elektronik yang terintegrasi melalui akses jaringan elektronik dan dihubungkan melalui jaringan internet atau jaringan lokal komputer. Hybrid library

${ }^{14}$ Aditya Nugraha. Open Access: menyuburkan plagiarisme dalam visi pustaka majalah perpustakaan (Jakarta:Perpusnas, 2009),19

${ }^{15}$ Repository.usu.ac.id/bitstream/123456789/53087/4/Chapter\%20II.pdf diakses pada tanggal 20 Juni 2017 
juga dapat diartikan sebagai continum antara perpustakaan konvensional dan perpustakaan digital, dimana informasi yang dikemas dalam media elektronik maupun cetak digunakan secara bersamaan. ${ }^{16}$ Ada beberapa perbedaan antara perpustakaan digital dan hibrida yaitu:

1. Hybrid library masih mempunyai koleksi tercetak yang yang permanen dan setara dengan koleksi digitalnya, dimana perpustakaan digital berusaha ingin mengubah semua koleksinya ke dalam bentuk digital.

2. Hybrid library memperluas konsep cakupan jasa informasi sehingga perubahan koleksi elektronik dan digital serta penggunaan teknologi komputer tidak dapat dipisahkan dari yang berbasis tercetak

Perpustakaan hibrida memperluas konsep dan cakupan jasa informasi, sehingga penambahan koleksi elektronik dan digital serta penggunaan teknologi komputer tidak dipisahkan dari jasa berbasis koleksi tercetak. Jasa koleksi tercetak diperluas dan dikelola secara lebih beragam lewat bantuan komputer. Dengan kata lain, perpustakaan hibrida bukan hanya perpustakaan tercetak dan elektronik, melainkan gabungan keduanya secara menyeluruh sehingga koleksi tercetak kini dimanfaatkan dengan cara berbeda dibandingkan sebelum ada komputer.

Dalam konsep-konsep perpustakaan hibrida, terdapat prinsip untuk mempertahankan keberadaan perpustakaan dengan koleksi tercetak, sebab pada dasarnya pemakai jasa masih memerlukan koleksi tersebut. Selain itu, ada banyak sekali karakter koleksi tercetak yang tidak dapat begitu saja tergantikan oleh digitalisasi. Buku cetak tidak tergantikan oleh buku digital, jurnal cetak tidak tergantikan oleh jurnal digital. Namun, dapat dikatakan pula keberadaan buku digital dan jurnal digital mengubah cara orang menggunakan buku dan jurnal tercetak. Perpustakaan hibrida memiliki beberapa kelebihan dibandingkan perpustakaan digital. Salah satunya,selain melakukan digitalisasi, hybrid library masih mempertahankan koleksi buku cetak. Sebab, pada dasarnya pemakai jasa masih memerlukan koleksi tersebut. Selain itu, karakter buku

\footnotetext{
${ }^{16}$ Putu Laxman Pendit. Perpustakaan Digital, 33
} 
cetak tidak bisa begitu saja tergantikan oleh e-book. Demikian pula jurnal cetak yang tak begitu saja bisa digantikan oleh jurnal digital.

Saat ini selain perpustakaan digital dan hibrida telah muncul pula perpustakaan bookless. Ini merupakan sebagai wujud dari perkembangan perpustakaan bookless. Perpustakaan bookless ini paradigmanya berbeda dengan perpustakaan hybrid yang mempunyai dua jenis koleksi cetak dan digital. Pada perpustakaan bookless ini tidak ada disediakannya koleksi tercetak. Untuk membaca koleksi dari perpustakaan bookless in ada alat yang dapat digunakan yaitu e -reader. Oleh sebab itu, bagi perpustakaan yang ingin menerapkan perpustakaan bookless ini harus memfasilitasi alat bacanya selain itu juga harus menyediakan desktop yang digunakan untu mengakses koleksi di tempat. Konsep dari perputsakaan ini adalah perpustakaan tanpa koleksi dalam bentuk tercetak.

\section{Kesimpulan}

Perkembangan teknologi yang terjadi saat ini sangat membantu perpustakaan dalam menghasilkan konsep-konsep perpustakaan. Perubahan-perubahan konsep perpustakaan dari konvensional hingga konsep perpustakaan bookless ini merupakan salah satu bukti bahwa perpustakaan mampu mengimbangi perkembangan teknologi tersebut. Perpustakaan yang mampu mengikuti perkembangan zaman akan meningkatkan citra perpustakaan di kalangan masyarakat.

Perpustakaan digital hadir untuk memberikan atau meringankan kelemahan-kelemahan yang terdapat pada perpustakaan konvensional. Perpustakaan digital merupakan terobosan yang sangat cepat dalam memaksimalkan fungsi dari perpustakaan. Bukan hanya itu saja terobosan-terobosan konsep perpustakaan yang selalu muncul juga menjadi salah satu upaya dalam memaksimalkan setiap tugas dan fungsi dari perpustakaan. Saat ini perpustakaan hybrid dan bookless sudah menjadi konsep perpustakaan yang sudah banyak diterapkan apalagi di luar negeri. Perpustakaan hybrid merupakan perpustakaan perpaduan antara perpustakaan konvensional dan digital yang terintegrasi melalui jaringan internet. Media elektronik dan cetak dalam perpustakaan hybrid ini digunakan secara bersamaan. Berbeda dengan perpustakaan bookless, perpustakaan ini tidak menyediakan koleksi 
tercetak. Untuk membaca koleksi pada perpustakaan bookless ini dibutuhkan alat yang dinamakan e-reader.

\section{Daftar Pustaka}

Dereau, J.M. dan D.W.G. Cleneans. Dasar-Dasar Pelestarian dan Pengawetan Bahan Pustaka: Principle For The Preservation and Konservation of Library Materials. Jakarta: Perpustakaan Nasional RI, 1990

Lasa HS.(2000). Leksikon Kepustakawanan Indonesia . Yogyakarta: Pustakawan UGM.

Nugraha, Aditya. Open Access: menyuburkan plagiarisme dalam visi pustaka majalah perpustakaan. Jakarta:Perpusnas, 2009

Pendit, Putu Laxman. Perpustakaan Digital dari A sampai Z. Jakarta: Cita Karyakarsa Mandiri, 2008

Sucahyo dan Yudho Giri. InfrastrukturPerpustakaan Digital. Jakarta: SagungSeto, 2006

Sulistyo-Basuki. Pengantar Ilmu Perpustakaan. Jakarta: Gramedia Pustaka Utama,1993

Widayanti, Yuyun. Pengelolaan Perpustakaan Digital. Jawa Tengah: STAIN Kudus, 2015

Yuadi, Imam. Perpustakaan Digital: Paradigma, Konsep dan Teknologi Informasi yang Digunakan. http://journal.unair.ac.id/filerPDF/PERPUSTAKAAN\%20DIGITAL. pdf

Repository.usu.ac.id/bitstream/123456789/53087/4/Chapter\% 20II.pdf 